\title{
The Efficacy of Posterior Resection of Inferior Turbinate on Patients Who Have Recurred Nasal Obstruction after Inferior Turbinate Surgery
}

\author{
Hyun Myung Oh, Nam Kook Kim, Joo Young Kim, \\ Dae Woong Kim, Dong Jin Choi, and Jang Soo Lee \\ Department of Otolayngology-Head and Neck Surgery, Kwangju Christian Hospital, Gwangju, Korea
}

\author{
하비갑개 수술 후 재발성 비폐색을 보이는 환자에서 하비갑개 후방 절제술의 효용성 \\ 오현명 · 김남국 · 김주영 · 김대웅 · 최동진 · 이장수 \\ 광주기독병원 이비인후과
}

Received September 29, 2013
Revised November 21, 2013
Accepted December 1, 2013
Address for correspondence
Jang Soo Lee, MD
Department of Otolayngology-
Head and Neck Surgery,
Kwangju Christian Hospital,
37 Yangnim-ro, Nam-gu,
Gwangju 503-715, Korea
Tel +82-62-650-5095
Fax +82-62-650-5090
E-mail ohmmymap@naver.com

\footnotetext{
서 론

비폐색을 유발하는 흔한 원인 중의 하나로 하비갑개의 만성 적 비후를 들 수 있으며, 그 원인으로는 알레르기 비염, 감염, 약물성 또는 혈관운동성 비염 등이 있다. 원인에 따라 비점막 수축제나 항히스타민제, 국소용 또는 경구용 스테로이드제 등 의 내과적 치료를 우선적으로 시행하며, 이에 반응이 없는 경 우 수술적 치료를 선택할 수 있다.

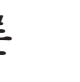

Background and Objectives Various surgical techniques have been tried to relieve nasal obstruction in patients who have hypertrophic inferior turbinate. Recently, coblators and microdebriders are the favored surgical procedure. This study is aimed at evaluating the long term efficacy of posterior resection of inferior turbinate performed on patients for whom the previous inferior turbinate surgery had not relieved the symptoms of nasal obstruction.

Subjects and Method We selected 27 patients who have had previous inferior turbinate surgery, but were not relieved of the symptom for nasal obstruction. Under local or general anesthesia, hypertrophied posterior part of inferior turbinate was removed. The symptom changes of nasal obstruction and patients satisfaction were checked pre and postoperatively at 1, 2, 3,6, 12 month by Visual Analogue Scale (VAS) score. The minimal cross-sectional area of second notch and volume of nasal cavity were measured at 1, 2, 3, 6, 12 month after operation.

Results There were significant improvement in the VAS score of nasal obstruction and patient satisfaction after the operation. The minimal cross-sectional area of second notch did not change significantly after surgery, but the nasal cavity volume was significantly improved after surgery.

Conclusion This study suggests that posterior resection of inferior turbinate is an effective surgical procedure for patients who have hypertrophic inferior turbinate especially on the posterior part.

Korean J Otorhinolaryngol-Head Neck Surg 2014;57(4):239-43

Key Words Nasal surgical procedures $\cdot$ Rhinitis $\cdot$ Turbinates. 
시 코블레이터와 미세절삭기를 이용한 수술의 장기적 효과를 비교해 보고한 바 있다. ${ }^{5)}$

저자들은 최근 하비갑개 수술을 받은 만성 비후성 비염 환 자들 중 다른 증상은 호전되었으나 코막힘의 증상이 호전을 보 이지 않은 몇몇 환자들을 관찰한 결과 공통적으로 하비갑개 후방의 비대로 인해 후비공이 폐쇄되어 있는 것을 발견하였으 며, 비대해진 하비갑개 후방을 일부 절제함으로써 코막힘의 증상 호전을 가져온 증례들을 분석해 후방 하비갑개 절제술 의 효용성을 알아보고자 하였다.

\section{대상 및 방법}

\section{대 상}

2012년 1월부터 12월까지의 기간에 비폐색을 주소로 본원 이비인후과에 내원한 환자들 중 하비갑개 수술을 받은 과거력 이 있는 환자들을 대상으로 하였으며, 심한 비중격 만곡증이 존재하거나 만성 부비동염, 비용종을 가진 환자, 하비갑개 전 단부의 비대가 남아있는 환자는 대상에서 제외하였다. 34명 의 환자 중 외래에서 보스민을 이용한 비점막 수축과 부비동 전 산화단층촬영을 통해 양측 하비갑개 후방의 비후가 확인된 27 명의 환자를 최종 대상자로 선정하였다.

환자들의 성비는 남자가 17 명, 여자가 10 명으로 평균 연령 은 44.3세였으며, 하비갑개 수술 후 본원에 내원하기까지의 평 균기간은 5.3개월이었다. 이전 하비갑개 수술의 종류는 코블레 이터를 이용한 경우가 18 명이었으며 나머지 9명은 본인이 받
은 술식에 대해 알지 못하였다.

술 후 추적관찰기간은 최소 3 개월에서 15 개월로 평균 12.3 개월이었다.

\section{수술 방법}

모든 수술은 동일 의사에 의하여 집도되었으며 환자는 국 소마취하에 수술을 시행하였고 환자가 원하는 경우 전신마취 하에 시행하였다. 자세는 앙와위를 취하고 혈관수축과 국소 마 취를 위해 술 전 처치로 4\% 리도카인과 1:100000 에피네프린 을 섞은 용액을 면거즈에 묻혀 약 15 분간 비강에 패킹하였다 가 제거하였으며, 이 때 하비갑개의 후방까지 충분히 패킹되도 록 하였다. 이후 $2 \%$ 리도카인을 이용하여 하비갑개 전반에 걸 쳐 침윤마취를 하였으며, 하비갑개 후방의 절제 전 하비갑개 의 내-외측 골절을 시행하였다.

이 후 하비갑개의 하방경계의 뒤쪽 $1 / 3$ 지점에서부터 외측 사 선방향으로 하비갑개의 뒤쪽 끝까지 conchotomy scissors로 절제하였다(Fig. 1). 이후 출혈은 보스민 거즈 패킹으로 조절하 였으며, 보스민 거즈로 지혈이 되지 않는 환자에게는 코블레이 터(Coblator, EVac 70, Arthrowant, Arthrocare corporation, Sunnyvale, CA, USA)를 이용하여 지혈하였다.

지혈이 된 것을 확인한 후에 비강내 패킹(merocel packing) 을 시행하고 퇴원하였으며 2일 후 외래에서 패킹을 제거하였다.

\section{수술 시간, 회복기간, 수술시 출혈, 수술 후 출혈}

수술 시간은 마취시간을 제외한 순수한 수술 시간만을 측
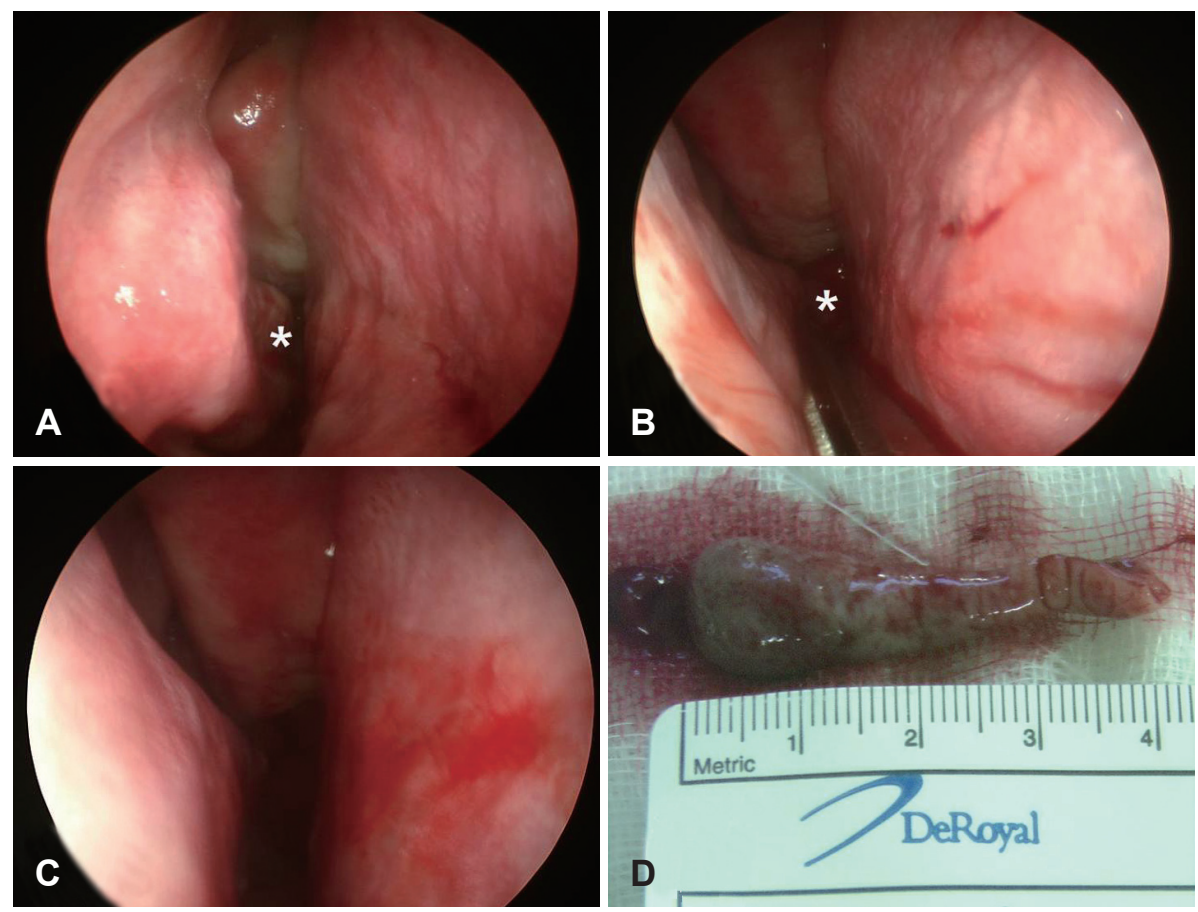

Fig. 1. Pictures show the procedure of posterior resection of inferior turbinate. Hypertrophied posterior part of inferior turbinate was observed $(A$, marked by *), and posterior part of inferior turbinate was resected by conchotomy scissors (B). Posterior resection of inferior turbinate was done (C) and removed tissue was shown (D). 
정하였고, 회복기간은 하비갑개에 가피가 생기지 않는 기간으 로 하였다. 수술 도중에 1:100000 에피네프린을 섞은 보스민 패킹으로 조절되지 않는 하비갑개 출혈이 있는 경우를 수술 시 출혈로 간주하였으며 회복기간 중에 출혈로 인해 비강 패 킹이나 전기 소작술이 필요했던 경우를 수술 후 출혈로 정의 하였다.

\section{증상의 개선도 및 환자의 만족도}

수술 후에 증상 개선 정도를 보기 위해 모든 환자에게 술 전 과 술 후 1 개월, 2 개월, 3 개월, 6 개월, 12 개월에 설문 조사를 시 행하였으며 증상의 개선도는 Visual Analogue Scale(VAS)을 이용하여 비폐색 증상의 개선도에 대한 설문조사를 시행하였 다. 0 점은 증상이 전혀 없는 상태로, 10 점은 증상이 가장 심한 상태로 설명하여 환자가 느끼는 주관적인 증상의 정도를 점수 로 내도록 하였다. 술 전 점수에서 술 후 점수를 뺀 점수로 증 상의 개선 정도를 판단하여 양의 값이 클수록 증상 개선이 좋 은 것으로 판단하였으며 0 일 경우 변화가 없는 것으로 음수인 경우 악화된 것으로 분석하였다. 설문 조사를 시행할 때 그 전 설문 조사와 비교하여 증상의 개선도와 지속 여부를 확인하 였으며, 수술 후 상태에 만족하는지에 대하여도 VAS를 이용 하여 질문하였다. 이때 증상의 만족도가 높을수록 10 점에 가 깝도록 하였으며 만족도가 낮을수록 0 점에 가깝게 표현하도 록 설명하였다.

\section{음향비강 통기도 검사}

수술 이후 객관적인 호전 정도를 비교하기 위하여 모든 환 자에게 술 전과 술 후 1 개월, 2 개월, 3 개월, 6 개월, 12 개월에 음 향비강 통기도 검사를 시행하였다. 비점막 수축제를 사용하지 않은 상태에서 비강내 분비물을 제거한 후 약 15 분 정도 안정 을 취하게 한 후에 피검자를 편안한 상태에서 의자에 바르게 앉게 하고 환자 몸과 접비구(nosepiece)의 장축이 약 15 도 정 도를 유지하게 한 후 호흡을 멈춘 상태에서 검사하였다. 접비 구를 비전정부에 밀착하되 비전정부가 찌그러지지 않도록 주 의하였다. 각 비강에 대하여 최소단면적(minimal cross section area, MCA)과 비공으로부터 후방 $7 \mathrm{~cm}$ 까지의 비강용적 (V7)을 구하였으며 양측 비강계측치의 평균값을 사용하였다.

\section{통계학적 분석}

통계학적 검증은 SPSS 17.0(SPSS Inc., Chicago, IL, USA) 을 이용하여 비모수검정인 Wilcoxon signed rank test로 분 석하였고, $p$ 값이 0.05 미만인 경우를 통계학적으로 유의한 것 으로 해석하였다.

\section{결 과}

수술 후 추적관찰, 수술 시간, 회복기간, 수술시 출혈,

\section{수술 후 출혈}

수술 후 3 개월까지 추적관찰 중 탈락한 사람은 없었다. 그러 나 이후 설문조사에서 6 개월째에 1 명, 12 개월째에 4 명의 환자 가 개인사정 등의 이유로 탈락하였고, 최종 통계분석에 포함된 환자는 22명이었다.

수술 소요시간은 한 쪽 비강을 수술하는 데 $10.7 \pm 1.6$ 분이었 으며, 회복기간은 $3.2 \pm 0.6$ 주였다.

수술시 보스민 거즈로 지혈이 되지 않는 출혈이 13 명에게서 발생하였으며 이는 코블레이터로 지혈하였다. 수술 후 출혈은 없었다.

수술 후 발생한 가장 많은 합병증은 하비갑개 절제부위에 생 긴 가피로 인한 비폐색감이었으며, 수술 직후부터 길게는 2주 째까지 호소하는 환자도 있었다. 급성 염증, 반복적인 비출혈, 협착, 건조감, 후각장애 등의 합병증은 관찰되지 않았다.

\section{비폐색의 개선도 및 환자의 만족도}

술 전에 비해 1 개월째부터 비폐색의 유의한 증상 개선이 이 루어졌으며, 그 효과는 1년까지 유지되었다.

환자의 만족도 역시 비폐색의 호전과 비슷하게 1 개월째부터 유의한 호전을 보여 1년까지 만족도가 잘 유지되었다(Table 1).

\section{음향비강 통기도 검사}

$\mathrm{MCA}$ 는 술 전과 비교하여 술 후에도 유의하게 큰 차이는 보 이지 않았다. V7은 술 후 1개월째부터 유의한 증가를 보여 1년 까지 유지되었다(Fig. 2).

\section{고 찰}

내과적 치료에 반응하지 않는 만성적인 하비갑개의 비후가

Table 1. The comparision between preoperative VAS score and postoperative VAS score checked at 1, 2, 3, 6, 12 month after operation for nasal obstruction and patient's satisfaction (mean $\pm S D$ )

\begin{tabular}{lll}
\hline & \multicolumn{2}{c}{ VAS score } \\
\cline { 2 - 3 } & $\begin{array}{c}\text { Nasal } \\
\text { obstruction }\end{array}$ & $\begin{array}{c}\text { Patient's } \\
\text { satisfaction }\end{array}$ \\
\hline Preoperative & $8.75 \pm 1.20$ & $2.55 \pm 0.81$ \\
Postoperative (1 month) & $2.44 \pm 0.82^{*}$ & $7.32 \pm 0.88^{*}$ \\
Postoperative (2 month) & $1.54 \pm 0.77^{*}$ & $8.54 \pm 0.47^{*}$ \\
Postoperative (3 month) & $1.76 \pm 0.60^{*}$ & $8.81 \pm 0.32^{*}$ \\
Postoperative (6 month) & $2.25 \pm 0.71^{*}$ & $8.25 \pm 0.31^{*}$ \\
Postoperative (12 month) & $2.82 \pm 0.93^{*}$ & $7.82 \pm 1.12^{*}$ \\
\hline * $<0.05$. VAS: Visual Analogue Scale, SD: standard deviation
\end{tabular}




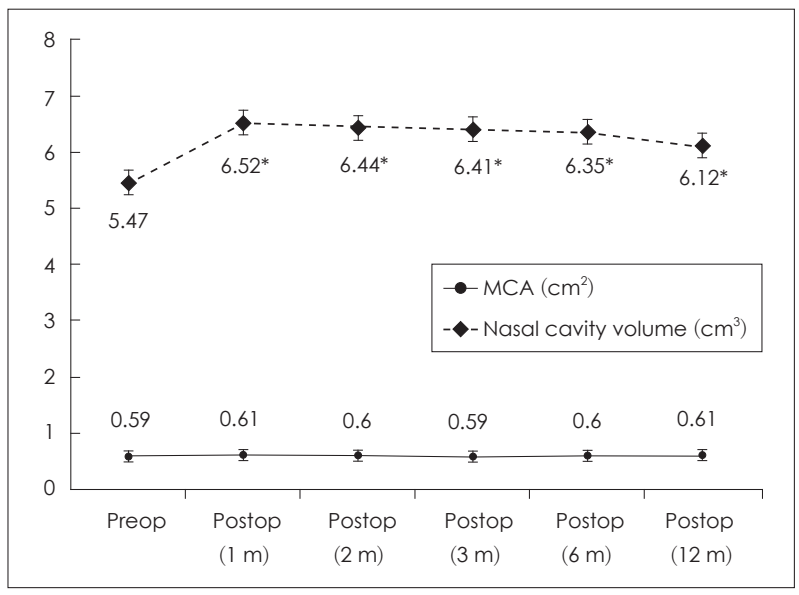

Fig. 2. Graph show the change of nasal patency in acoustic rhinometry measured at 1, 2, 3, 6, 12 months after operation (mean \pm SD). MCA: minimal cross sectional area $(* p<0.05)$.

있는 경우에 수술은 효과적인 치료법 중의 하나이며, 하비갑개 의 기능을 보존하면서 합병증 없이 증상을 호전시키는 것이 최 선의 목표라고 할 수 있다.) 이를 위해 예전부터 여러 가지 하 비갑개 수술 방법이 시도되어 왔으나, 각각의 술기는 그 나름 대로 장점과 함께 단점 역시 가지고 있다.

하비갑개 전절제술이나 부분 절제술의 경우 정도의 차이는 있으나 하비갑개의 점막과 호흡상피를 파괴함으로써 하비갑 개 점막의 생리적 기능이 손상된다는 한계를 가지고 있으며,7, 이러한 단점을 보완하기 위해 최근에는 코블레이터나 미세절 삭기를 이용한 상대적으로 비침습적인 수술이 많이 시행되고 있는 추세이다.

코블레이터는 무선 주파를 이용한 기구로 전기소작이나 레 이저에 비해 상대적으로 낮은 저온의 열(40 90도)을 발생시 킴으로써 조직을 파괴하고, 이후 회복과정 중 조직의 섬유화 를 유도하여 하비갑개 점막층의 부피 축소를 유발한다. ${ }^{9}$

미세절삭기를 이용한 하비갑개 성형술은 1990년대 중반부 터 소개되었으며 술자에 따라 하비갑개의 외부에서 과다한 점 막표면과 점막하층 일부를 제거하는 방법이나 하비갑개 전단 부에 절개를 가한 뒤에 $2 \mathrm{~mm}$ 팁을 삽입하여 점막표면을 보존 하면서 점막하층을 감소시켜주는 방법을 사용한다. ${ }^{10-13)}$

코블레이터나 미세절삭기를 이용한 하비갑개 성형술의 경 우 최소침습으로 최대의 효과를 노리기 위해 주된 수술부위 를 하비갑개의 전단으로 삼으며 그 이유는 비 호흡시 저항을 야기하고 증상을 유발하는 주된 부분이 하비갑개의 전단부 라는 사실에 근거를 두고 있다. ${ }^{14-16)}$

이러한 코블레이터와 미세절삭기를 이용한 하비갑개 성형 술로 많은 증상 호전을 가져왔다고 여러 저자들이 보고하고 있으며, ${ }^{1-4)}$ 본 저자들 역시 코블레이터와 미세절삭기를 이용한 수술의 장기적 효과를 비교해 보고한 바 있다.5)
하지만 저자들은 하비갑개 수술 후 콧물, 재채기 등 다른 증 상들은 호전되었으나 비폐색이 호전되지 않고 남아있는 환자 들을 드물지 않게 볼 수 있었으며, 이런 환자들의 대부분에서 하비갑개 후방의 비후로 인해 후비공이 막혀 있는 소견을 관 찰할 수 있었다.

몇몇 논문에서도 하비갑개 골부의 비후나 하비갑개 후방의 비후가 남아있는 경우 하비갑개 성형술의 효과가 떨어졌다고 보 고하고 있으며, 이는 저자들이 경험한 환자들과 유사하였다.1,17)

저자들의 경우 34 명의 환자들 중 27 명의 환자들에게서 하 비갑개 후방의 비후를 확인할 수 있었고, 나머지 7명의 환자들 은 하비갑개 골부의 비후만 가지고 있는 경우나 하비갑개 전 단부의 비대가 아직 남아있는 경우가 있었다. 27 명의 대상자 들은 이전의 하비갑개 수술로 인해 전단부의 비대는 없는 상 태였음에도 불구하고 비폐색을 지속적으로 호소하였으며, 저 자들은 그 원인을 후비공을 막고 있는 하비갑개 후방의 비후 로 보았다. 후방의 비후가 남아있는 원인은 본원에 내원한 환 자들이 모두 개인 의원에서 수술을 받은 경력이 있는 것으로 보아 수술시 하비갑개 후방을 충분히 관찰하지 못한 것이 영 향을 미쳤을 것으로 생각된다. 하비갑개 후방의 비후를 해결하 기 위해 하비갑개 부분 절제술을 시행하였으며, 기존의 전절 제술이나 부분 절제술이 전단부를 손상시키는 단점이 있기 때 문에 전단부를 제외한 후방의 비후된 부분만을 절제하였다.

하비갑개 후방 절제술 전 하비갑개의 내-외측 골절을 시행 하였으며, 그 이유는 하비갑개 골부의 외측화를 통해 보다 효 과적인 하비갑개 축소를 이끌어내고, 하비갑개 후방을 충분 히 노출시키기 위해서였다.

수술 후 1 개월째부터 비폐색의 호전을 보였으며 그 효과가 장기간 유지되었고, 환자들의 만족도 또한 같은 결과를 보였 다. MCA가 수술 후에도 큰 변화를 보이지 않았던 것으로 볼 때, 이는 하비갑개 후방의 비후로 인한 후비공의 폐쇄가 비폐 색을 일으키는 주된 원인이었다고 생각할 수 있다.

수술 중 보스민 거즈로 지혈되지 않는 출혈이 발생하였는 데, 이는 충분한 국소 마취가 이루어지지 않았던 경우가 있었 던 것으로 생각되며, 대부분의 경우 활동성 출혈은 없었고, 코 블레이터를 이용한 소작술만으로도 지혈되었다. 수술 후 환자 들이 가장 많이 호소하였던 합병증은 비폐색감이었는데, 이 는 하비갑개 절제 부위의 가피 형성으로 인한 일시적인 현상 이었으며, 회복 후 모두 개선되었다.

정상적인 비강의 생리적 기능에도 큰 영향은 없었으며, 수 술 이후 외래 추적관찰 기간 동안 불편감을 호소하는 환자는 없었다. 이는 기존의 하비갑개 전절제술이나 부분 절제술이 유 발하는 빈 코 증후군(empty nose syndrome) 등의 여러 합병 증을 피하면서 환자의 증상을 개선시킬 수 있다는 것을 보여 
주는 것이라고 생각된다.

하지만, 기존의 하비갑개 전절제술이나 부분 절제술과의 직 접적인 비교가 없으며, 명확한 대조군이 설정되지 않은 점은 본 연구의 아쉬운 부분이다. 또한 수술 시야의 확보를 위해서 이긴 하지만 내-외측 골절을 시행한 것도 비폐색의 호전에 기 여했을 가능성이 있어 결과에 영향을 주었을 가능성도 배제 할 수 없다. 추적관찰 기간이 1년이라는 점은 좀 더 장기적인 추적관찰을 필요로 할 것이라고 생각된다.

\section{REFERENCES}

1) Lee JY, Lee JD. Comparative study on the long-term effectiveness between coblation- and microdebrider-assisted partial turbinoplasty. Laryngoscope 2006;116(5):729-34.

2) Liu CM, Tan CD, Lee FP, Lin KN, Huang HM. Microdebriderassisted versus radiofrequency-assisted inferior turbinoplasty. Laryngoscope 2009;119(2):414-8.

3) Cingi C, Ure B, Cakli H, Ozudogru E. Microdebrider-assisted versus radiofrequency-assisted inferior turbinoplasty: a prospective study with objective and subjective outcome measures. Acta Otorhinolaryngol Ital 2010;30(3):138-43.

4) Kizilkaya Z, Ceylan K, Emir H, Yavanoglu A, Unlu I, Samim E, et al. Comparison of radiofrequency tissue volume reduction and submucosal resection with microdebrider in inferior turbinate hypertrophy. Otolaryngol Head Neck Surg 2008;138(2):176-81.

5) Lee JS, Min HK, Kim NK, Oh HM, Son WS, Park BC. The long term efficacy of microdebrider assisted versus coblation assisted inferior turbinoplasty. Korean J Otorhinolaryngol-Head Neck Surg 2011;54(8):532-8.

6) Hol MK, Huizing EH. Treatment of inferior turbinate pathology: a review and critical evaluation of the different techniques. Rhinology 2000;38(4):157-66

7) Passàli D, Passàli FM, Damiani V, Passàli GC, Bellussi L. Treatment of inferior turbinate hypertrophy: a randomized clinical trial. Ann Otol Rhinol Laryngol 2003;112(8):683-8.

8) Sapçi T, Sahin B, Karavus A, Akbulut UG. Comparison of the effects of radiofrequency tissue ablation, $\mathrm{CO} 2$ laser ablation, and partial turbinectomy applications on nasal mucociliary functions. Laryngoscope 2003;113(3):514-9.

9) Lim DJ, Kang SH, Kim BH, Cho YC, Oh DH, Jung MS, et al. Treatment of allergic rhinitis using bipolar radiofrequency-assisted partial turbinoplasty. Korean J Otolaryngol-Head Neck Surg 2005; 48(9):1102-6.

10) Van delden MR, Cook PR, Davis WE. Endoscopic partial inferior turbinoplasty. Otolaryngol Head Neck Surg 1999;121(4):406-9.

11) Wexler D, Braverman I. Partial inferior turbinectomy using the microdébrider. J Otolaryngol 2005;34(3):189-93.

12) Hong SK, Yoon SO, Park SK, Son JY, Kim EA, Cho YH, et al. Laserassisted versus coblation-assisted partial turbinoplasty: comparison by their postoperative outcome. Korean J Otolaryngol-Head Neck Surg 2002;45(6):589-93.

13) Friedman M, Tanyeri H, Lim J, Landsberg R, Caldarelli D. A safe, alternative technique for inferior turbinate reduction. Laryngoscope 1999;109(11):1834-7.

14) Grymer LF, Illum P, Hilberg O. Septoplasty and compensatory inferior turbinate hypertrophy: a randomized study evaluated by acoustic rhinometry. J Laryngol Otol 1993;107(5):413-7.

15) Kim CS, Moon BK, Jung DH, Min YG. Correlation between nasal obstruction symptoms and objective parameters of acoustic rhinometry and rhinomanometry. Auris Nasus Larynx 1998;25(1): 45-8.

16) Croce C, Fodil R, Durand M, Sbirlea-Apiou G, Caillibotte G, Papon $\mathrm{JF}$, et al. In vitro experiments and numerical simulations of airflow in realistic nasal airway geometry. Ann Biomed Eng 2006;34(6): 997-1007.

17) Choi SC, Lim DJ, Kang SH, Kim BH, Kim HS, Ahn JY. Inferior turbinate surgery for chronic hypertrophic rhinitis: comparison of three techniques. Korean J Otorhinolaryngol-Head Neck Surg 2008; 51(7):630-5. 